\title{
Teaching in Times of COVID-19 Pandemic in Two Peripheral Greek Universities: Lessons Learned from Students' Experiences and Opinions
}

Natassa Raikou: Laboratory of Pedagogical Research and Lifelong Education, Department of Educational Science and Early Childhood Education University of Patras, Greece.

Chris Kaltsidis: Laboratory of Teaching and Professional Development of Bioscientists, Department of Molecular Biology and Genetics Democritus University of Thrace, Greece.

Katerina Kedraka: Laboratory of Teaching and Professional Development of Bioscientists, Department of Molecular Biology and Genetics Democritus University of Thrace, Greece.

-Thanassis Karalis: Laboratory of Pedagogical Research and Lifelong Education, Department of Educational Science and Early Childhood Education University of Patras, Greece.

ABSTRACT: COVID-19 pandemic has affected many aspects of social and economic life, including the educational sector. While each level of education faces its unique challenges, for the Higher Education the pandemic may act as the catalyst triggering a learning revolution. In the current study, which took place in April-May 2020, in the middle of lockdown in Greece, students from two regional Universities in Greece who participated pointed out that the Covid-19 pandemic disturbed their studies, even though their institutions managed to turn very quickly and successfully to distance learning. Despite the fact they are both old enough to handle the online work and technologically savvy enough to navigate new, digital tools and methods, a lot of anxiety, doubts and concerns arose. The main finding is that Greek students found it difficult to handle the lack of the everyday campus life and interaction with their fellow students and teachers, a lesson learnt for faculty to add pedagogically interactive tools, experiences, and ideas to stimulate students" learning engagement.

Key words: Higher education pedagogy, COVID-19 pandemic, University, Online learning, E-learning.

International Journal of Educational Studies

Vol. 3, No.1, pp. 24-35

2020

DOI: $10.53935 / 2641-533 x . v 3 i 1.137$

Corresponding Author: Thanassis Karalis Funding: This study received no specific financial support.

Article History:

Received: 13 January 2020

Revised: 17 February 2020

Accepted: 25 March 2020

Published: 20 April 2020

(C) 2020 by the authors; licensee Academic

Publishing Group

\section{Introduction}

Due to the coronavirus crisis, Universities worldwide have faced sudden pressure to shift from faceto-face delivering of courses to digitally enhanced teaching - blended and/or online learning. This crisis undoubtedly caused a degree of inconvenience, but it could also be considered as an opportunity for Universities to trigger the use of digital tools for enhancing the quality of learning and teaching. This need, once established and evaluated, should be supported by investment in digital infrastructure and the developing of good practices, combined with faculty training. As quality online education is expensive and it will need not only further investment but also further evidence to ensure that the new opportunity for digitally enhanced learning is taken up (Murphy, 2020), it is important to investigate the students" and educators" attitudes and needs towards these approaches, as they both now have extensive experience 
following one full semester with online courses. This is the concept of the current study, which took place in April-May 2020 in two Greek Universities that have a lot of common characteristics.

Following Coombs" seminal work on crises in education (Coombs, 1968), natural disasters and sanitary crises seemed to be out of the scope of researchers in educational policy, at least in developed countries. Relevant literature elaborated crises as instabilities in education systems caused mainly by the failure of formal education organizations in responding to societal needs. After the outbreak of COVID19 pandemic, crisis management entered enormously in literature focusing mainly on the ways educational systems could maintain their normal operation under the new threatening external conditions (Karalis, 2020). On the other hand, a considerable amount of research work so far, focused on the implications of educational disruption in teaching practices since most education systems tried to follow solutions based on remote teaching or distance education. Tertiary and higher education organizations were among the educational activities that were seriously impacted by the disruption of normal operation and the lock- down in almost all countries of the world. For the first wave of the pandemic, the most crucial period was in April 2020. According to UNESCO Institute for Statistics Data on $10^{\text {th }}$ of April 2020 , more than 1,5 billion students $(90,1 \%$ of the total enrolled students in all educational organizations) in 192 countries were not participating in educational activities due to local or national lockdowns. The situation seemed to deescalate during the next months, but in almost all countries concerns for the future and the second pandemic wave are present. The research presented afterwards refers to the effect of COVID-19 pandemic on teaching in two Greek Universities and the possible implications for higher education pedagogy.

\section{COVID-19 Pandemic and Higher Education Pedagogy}

As already mentioned, following the outbreak of COVID-19 pandemic almost all higher education organizations tried to continue their operation, mostly using solutions of remote teaching based on the Internet. Of course, one could point out a matter of inequality since solutions like these were not easy to be implemented in many parts of the world (see indicatively: (Schleicher, 2020; UNESCO, 2020) as well as for vulnerable social groups in developed countries. In most cases, a combination of synchronous and asynchronous solutions was used to facilitate the continuation of education under these unprecedented conditions.

It is remarkable that research worldwide focused on two main axes. The first of them is related to the impact of the pandemic crisis in the operation of higher education institutes and the consequences for the future. The term low-density University coined by Maloney and Kim (2020) is a vivid description of the conditions under which Universities should operate for the next period, while scenarios and concerns for the prospective image of higher education determine the agenda for the present situation as well as the day after. On the other hand, the second axis of research is related to the implications of disruption and the transition to online teaching, to students and teachers and the possible alteration of pedagogical practices in the near future. Osmosis with practices of online teaching is an enormous factor that could lead to a differentiation of the modes by which University courses are taught. Learning in virtual environments, curriculum design, course development, tools for synchronous and asynchronous learning, soft skills, laboratory simulation, are some of the issues arisen in the research agenda, following the long-term exposure of both professors and students in this new environment for teaching and learning.

In Greece, all types of educational activities were suspended by March 11, 2020 after the Joint Ministerial Decision 16838. All Greek Universities started huge efforts to implement the transition in online learning. Although this was considered to be a very demanding task, because of issues related to crisis management, development of educational material, training of the teaching personnel, and other crucial factors (Karalis, 2016, 2020), the majority of Greek Universities managed to offer online more than $90 \%$ of their courses by the end of March 2020. University of Patras was the first University all over Greece to suspend its activities due to a local lockdown but managed to offer almost all courses online by the end of the second week. Democritus University of Thrace, begun to offer almost all courses online by the end of March 2020, two weeks after the disruption of its educational operation.

Although Higher Education or University Pedagogy emerged as a new field during the decade of 1960, in Greece this new field started to produce research results very recently following the

\begin{tabular}{l} 
International Journal of Educational \\
Studies \\
Vol. 3, No.1, pp. $24-35$ \\
2020 \\
DOI: $10.53935 / 2641-533 x . v 3 i 1.137$ \\
Corresponding Author: Thanassis Karalis \\
Funding: This study received no specific \\
financial support. \\
Article History: \\
Received: 13 January 2020 \\
Revised: 17 February 2020 \\
Accepted: 25 March 2020 \\
Published: 20 April 2020 \\
() 2020 by the authors; licensee Academic \\
Publishing Group \\
\hline | 25
\end{tabular}




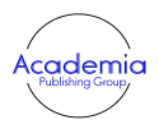

International Journal of Educational Studies

Vol. 3, No.1, pp. 24-35

2020

DOI: $10.53935 / 2641-533 x . v 3 i 1.137$

Corresponding Author: Thanassis Karalis Funding: This study received no specific financial support.

Article History:

Received: 13 January 2020

Revised: 17 February 2020

Accepted: 25 March 2020

Published: 20 April 2020

(C) 2020 by the authors: licensee Academic

Publishing Group establishment of the Greek University Pedagogy Network at 2016 (Gougoulakis, Kedraka, Oikonomou, \& Anastasiades, 2020; Kedraka \& Rotidi, 2017). The main topics of this research include the role of academic teachers, the characteristics of students, emerging adulthood, and the development of critical thinking skills for the students of tertiary education (N. Raikou \& Karalis, 2011; Natassa Raikou, Karalis, \& Ravanis, 2017).

At the moment concerning the transition to online teaching in Greek higher education organizations, there are just a few research efforts published. Except the two works published by the authors of this article, which we will present in a comparative basis afterward, we should mention the research conducted by another research team at the University of Patras, having as main aim to investigate the adaptation of young students to the emerged situation (Kamarianos, Adamopoulou, Lambropoulos, \& Stamelos, 2020). What derives from the results of this research project is that as long as the Universities were closed most of the students did not have any difficulty in switching to online teaching, while they were very open to learn the new required skills and make new experiences. Giavrimis and Nikolaou (2020) showed that in the COVID-19 pandemic context high social capital can create the proper conditions for positive social relations and student interactions. According to the results of another study in the Greek higher education context, set out from the concepts of biographical rapture and transformation shifts in students" way of thinking and acting were detected, while no perspective transformation occurred (Charissi, 2020; Charissi, Tympa, \& Karavida, 2020).

A few days after the transition of educational activities in online mode, that is by the end of March 2020, we decided to conduct a twinned study in two Departments of the aforementioned Universities. More specifically this study is a joined research project, undertaken by two Laboratories of the University of Patras and Democritus University of Thrace, namely the Laboratory of Pedagogical Research and Lifelong Education (Department of Educational Science and Early Childhood Education DESECE) and the Laboratory of Teaching and Professional Development of Bioscientists (Department of Molecular Biology and Genetics - MBG). The idea of conducting this research project was based on the one hand in similarities of those two Universities, as University of Patras and Democritus University of Thrace are both peripheral Universities, therefore, most students" family homes are far from the campus. According to unpublished data from MBG"s record files, only a $8 \%$ of students" family city is Alexandroupolis and the nearby areas, while at the exams during pandemic just $27,5 \%$ of students of DESECE participated with internet connection from Patras. Meaning that the majority of students have their permanent (family) residence far from the two campuses.

So, when the shutdown of Universities was announced, the great majority of students returned home and continued their studies via digital tools and platforms. On the other hand, the Departments selected have significant dissimilarities. DESECE is a department of Education, with many theoretical courses alongside combined by a practicum in preschool education settings and the vast majority of students are female. MBG is a department of Health Sciences having a huge laboratory work.

In this paper, we present the results of both studies (Karalis \& Raikou, 2020; Kedraka \& Kaltsidis, 2020) in a comparative perspective aiming at investigating similarities and differences in students" experience and opinions.

\section{Methodology}

The aim of both studies, carried out with the same questionnaire (therefore, considered as „twin studies) was to investigate the emotions of students experienced during the first period of transition to online mode, the differences they encounter with the previous environment, and their possible deficiencies to follow classes with the new mode of education. For each study data was collected in the very first weeks to record students "fresh" experience for the new reality.

The questionnaire consisted of thirteen questions: six of them of closed-type, with a total of 34 items on a Likert-type scale (not at all, a little, quite, much, very much) and seven open-ended questions. Open-ended questions were put first so that the respondents would not be influenced by the proposed answers to close-ended questions. For the DESECE 103 questionnaires were selected in two different courses, (a) Planning and Evaluation of Adult Education Programs and (b) Reflection on Practicum. All participants were in the two last years of their studies and at the period of data collection they had already participated in four meetings in both courses. For MBG, 75 students participated in the study 
(62,7\% women and $37,7 \%$ men), who followed two courses: a) Pedagogy and b) Teaching Methodology, 53,3\% being sophomores (2nd year of studies), 41,3\% juniors and 5,3\% seniors who had not pass the courses during the previous years.

\section{Results}

4.1. Feelings at the Time the University Suspended Face-to-Face Courses

The students at the University of Patras (UP) and Democritus University of Thrace (DUTH) were asked about their feelings when the University suspended its educational function due to the pandemic of COVID-19. Based on the emotions that arose when the closure of University was announced, the majority of students in both Universities felt negative emotions, which mainly included anxiety and concern. In particular, students from both Universities (DUTH -UP) express no or a little indifference, because the interruption of courses bothered almost all of them (90.7\%-99\%), and the majority felt not at all or only a little joy at classes not being held, especially at the Democritus University of Thrace (70.7\%-58.3\%). The dominant feelings were concern (much/very much) about when and how the studies will be completed (70.7\%-90.3\%) and curiosity about what would happen to their studies (73.3\%-86.4\%). They also expressed fear whether they could abruptly continue their studies (50.7\%$83.5 \%)$, as well as sorrow over the interruption of their studies $(42.7 \%-68 \%)$. Nevertheless, the intensity of the negative emotions of the students of DUTH seems much lower than the students of UP. In general, it is notable that, when the Universities closed due to the pandemic, the emotions of the students of the DUTH, compared to the students of the UP, seem to be either a little calmer or more indifferent to the situation that had been developed. According to the Table 1, students from the University of Patras were more concerned about the completion of their studies in comparison to students from the University of Thrace.

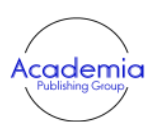

International Journal of Educational Studies

Vol. 3, No.1, pp. 24-35

2020

DOI: $10.53935 / 2641-533 x . v 3 i 1.137$

Corresponding Author: Thanassis Karalis Funding: This study received no specific financial support.

Article History:

Received: 13 January 2020

Revised: 17 February 2020

Accepted: 25 March 2020

Published: 20 April 2020

(C) 2020 by the authors; licensee Academic

Publishing Group
Table-1. Emotions of students when the Universities closed due to the COVID-19 pandemic

\begin{tabular}{|c|c|c|c|c|c|c|c|c|c|c|c|c|}
\hline \multirow{3}{*}{$\begin{array}{l}\text { Democritus } \\
\text { University of } \\
\text { Thrace } \\
\text { Initial Emotions }\end{array}$} & \multicolumn{12}{|c|}{ University of Patras } \\
\hline & \multicolumn{2}{|c|}{ Not at all } & \multicolumn{2}{|c|}{ A little } & \multicolumn{2}{|c|}{ Quite } & \multicolumn{2}{|c|}{ Much } & \multicolumn{2}{|c|}{$\begin{array}{l}\text { Very } \\
\text { much }\end{array}$} & \multicolumn{2}{|c|}{ Total } \\
\hline & $\mathrm{N}$ & $\%$ & $\mathrm{~N}$ & $\%$ & $\mathrm{~N}$ & $\%$ & $\mathrm{~N}$ & $\%$ & $\mathrm{~N}$ & $\%$ & $\mathrm{~N}$ & $\%$ \\
\hline Joy at classes not & 24 & 32 & 29 & 38.7 & 9 & 12 & 8 & 10.7 & 5 & 6.7 & 75 & 100 \\
\hline being held & 35 & 34 & 25 & 24.3 & 23 & 22.3 & 12 & 11.7 & 8 & 7.8 & 103 & 100 \\
\hline $\begin{array}{l}\text { Curiosity about } \\
\text { what }\end{array}$ & 4 & 5.3 & 5 & 6.7 & 11 & 14.7 & 27 & 36 & 28 & 37.3 & 75 & 100 \\
\hline would happen & 0 & 0 & 7 & 6.8 & 7 & 6.8 & 34 & 33 & 55 & 53.4 & 103 & 100 \\
\hline Fear of the & & & & & & & & & & & & \\
\hline $\begin{array}{l}\text { possibility of non- } \\
\text { continuation of }\end{array}$ & 8 & 10.7 & 19 & 25.3 & 10 & 13.3 & 20 & 26.7 & 18 & 24 & 75 & 100 \\
\hline studies & 2 & 1.9 & 6 & 5.8 & 9 & 8.7 & 21 & 20.4 & 65 & 63.1 & 103 & 100 \\
\hline Sorrow over the & 8 & 10.7 & 11 & 14.7 & 24 & 32 & 17 & 22.7 & 15 & 20 & 75 & 100 \\
\hline $\begin{array}{l}\text { interruption } \\
\text { studies }\end{array}$ & 3 & 2.9 & 9 & 8.7 & 21 & 20.4 & 35 & 34 & 35 & 34 & 103 & 100 \\
\hline $\begin{array}{l}\text { Concern about } \\
\text { when and how the } \\
\text { courses }\end{array}$ & 4 & 5.3 & 9 & 12 & 9 & 12 & 29 & 38.7 & 24 & 32 & 75 & 100 \\
\hline will be completed & 0 & 0 & 4 & 3.9 & 6 & 5.8 & 18 & 17.5 & 75 & 72.8 & 103 & 100 \\
\hline $\begin{array}{l}\text { Indifference, } \\
\text { because }\end{array}$ & 63 & 84 & 5 & 6.7 & 3 & 4 & 1 & 1.3 & 3 & 4 & 75 & 100 \\
\hline it did not bother me & 98 & 95.1 & 4 & 3.9 & 1 & 1 & 0 & 0 & 0 & 0 & 103 & 100 \\
\hline
\end{tabular}

4.2. Students' Emotions at the Time of the Survey 
The students were asked how they felt when the courses restarted. When online classes started, the majority in both Universities stated a clear change of emotions, mainly towards a positive direction. They expressed satisfaction and joy that the semester would not be lost.

In particular, as for the intensity of dominant emotions during online training (Table 2), we can observe that relief (much/very much) because the semester will not be lost was expressed by $86.6 \%$ of the participants at the Democritus University of Thrace and $95.2 \%$ at the University of Patras, while curiosity about how to continue their studies was noted by 69.4 and $70.9 \%$ respectively.

Nevertheless, the intense of the positive emotions seems much greater at the students of UP in comparison to the students of. More specifically, they express significantly more joy at the continuity of the lessons (DUTH: 60\% - UP: 91.3\%), more pleasure that no commuting is required for the course (44\%-70.9\%), as well as much more enthusiasm for the new experience $(21.3 \%-70.9 \%)$. This is in accordance with the intensity of disappointment with the new educational environment, where the differentiation between the two Universities is clear: $48 \%$ of the DUTH participants and $80.6 \%$ of the UP participants showed no or little disappointment with the new educational environment. In other words, students from the UP are more enthusiastic than students from the DUTH about the way the courses have continued. Students from the DUTH do not seem to be particularly excited by the new experience of distance learning, while, on the contrary, the vast majority of the students from the UP feel joy, pleasure and comfort about the new way of online education.

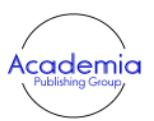

International Journal of Educational Studies

Vol. 3, No.1, pp. 24-35

2020

DOI: $10.53935 / 2641-533 x . v 3 i 1.137$

Corresponding Author: Thanassis Karalis Funding: This study received no specific financial support.

Article History:

Received: 13 January 2020

Revised: 17 February 2020

Accepted: 25 March 2020

Published: 20 April 2020

(C) 2020 by the authors; licensee Academic

Publishing Group
Table-2. Students ${ }^{\text {ee }}$ emotions during online education

\begin{tabular}{|c|c|c|c|c|c|c|c|c|c|c|c|c|}
\hline \multirow{3}{*}{$\begin{array}{l}\text { Democritus } \\
\text { University of } \\
\text { Thrace } \\
\text { Initial Emotions }\end{array}$} & \multicolumn{12}{|c|}{ University of Patras } \\
\hline & \multicolumn{2}{|c|}{ Not at all } & \multicolumn{2}{|c|}{ A little } & \multicolumn{2}{|c|}{ Quite } & \multicolumn{2}{|c|}{ Much } & \multicolumn{2}{|c|}{$\begin{array}{l}\text { Very } \\
\text { much }\end{array}$} & \multicolumn{2}{|c|}{ Total } \\
\hline & $\mathrm{N}$ & $\%$ & $\mathrm{~N}$ & $\%$ & $\mathrm{~N}$ & $\%$ & $\mathrm{~N}$ & $\%$ & $\mathrm{~N}$ & $\%$ & $\mathrm{~N}$ & $\%$ \\
\hline $\begin{array}{l}\text { Joy at continuing } \\
\text { the }\end{array}$ & 5 & 6.7 & 5 & 6.7 & 20 & 26.7 & 28 & 37.3 & 17 & 22.7 & 75 & 100 \\
\hline lessons & 0 & 0 & 1 & 1 & 8 & 7.8 & 50 & 48.5 & 44 & 42.7 & 103 & 100 \\
\hline $\begin{array}{lr}\begin{array}{l}\text { Pleasure } \\
\text { having }\end{array} & \text { not } \\
\text { commute } & \text { to } \\
\text { attend } & \end{array}$ & 12 & 16 & 14 & 18.7 & 16 & 21.3 & 18 & 24 & 15 & 20 & 75 & 100 \\
\hline classes & 6 & 5.8 & 12 & 11.7 & 21 & 20.4 & 20 & 19.4 & 44 & 42.7 & 103 & 100 \\
\hline $\begin{array}{l}\text { Relief that I will } \\
\text { not }\end{array}$ & 3 & 4 & 2 & 2.7 & 5 & 6.7 & 31 & 41.3 & 34 & 45.3 & 75 & 100 \\
\hline lose the semester & 0 & 0 & 1 & 1 & 4 & 3.9 & 11 & 10.7 & 87 & 84.5 & 103 & 100 \\
\hline $\begin{array}{l}\text { Enthusiasm for } \\
\text { the new }\end{array}$ & 16 & 21.3 & 17 & 22.7 & 26 & 34.7 & 9 & 12 & 7 & 9.3 & 75 & 100 \\
\hline $\begin{array}{l}\text { experience } \\
\text { Disappointment }\end{array}$ & 3 & 2.9 & 7 & 6.8 & 29 & 28.2 & 24 & 23.3 & 40 & 38.8 & 103 & 100 \\
\hline $\begin{array}{l}\text { that the new } \\
\text { educational } \\
\text { environment does } \\
\text { not }\end{array}$ & 18 & 24 & 18 & 24 & 18 & 24 & 13 & 17.3 & 8 & 10.7 & 75 & 100 \\
\hline work me & 53 & 51.3 & 30 & 29.1 & 17 & 16.5 & 3 & 2.9 & 0 & 0 & 103 & 100 \\
\hline $\begin{array}{l}\text { Curiosity about } \\
\text { how }\end{array}$ & 4 & 5.3 & 4 & 5.3 & 15 & 20 & 23 & 30.7 & 29 & 38.7 & 75 & 100 \\
\hline $\begin{array}{l}\text { studies } \\
\text { continue }\end{array}$ & 2 & 1.9 & 10 & 9.7 & 18 & 17.5 & 36 & 35 & 37 & 35.9 & 103 & 100 \\
\hline
\end{tabular}


Evaluating the online mode of education, in relation to the usual context, students point out some positive and negative characteristics. From the students" assessment of the new educational environment, it is evident that positive aspects of distance learning were mostly considered for both Universities (much/very much) the understanding of the course content (62.7\%-73.8\%), the development of new skills (56\%-86.4\%), and the convenience of attending courses (53.3\%-73.8\%). As we can see (Table 3), the vast majority of UP students $(86.4 \%)$ believe that the process will help them acquire better skills related to distance learning, possibly because they feel that it will be useful to them later and in their professional career as teachers, while for the DUTH students the most preferable characteristic was that the content of the course is comprehensible $(62.7 \%)$.

However, a large percentage of the UP students but a small percentage of the DUTH students consider (much/very much) the new way of teaching as interesting (37.4\%-72.8\%), the student participation in the course as great $(36 \%-70.8 \%)$ and the communication with the teacher as satisfactory

Table-3. Assessment of the new educational environment (compared to the previous one)

\begin{tabular}{|c|c|c|c|c|c|c|c|c|c|c|c|c|}
\hline \multirow{3}{*}{$\begin{array}{l}\text { Democritus } \\
\text { University of } \\
\text { Thrace } \\
\text { Initial Emotions }\end{array}$} & \multicolumn{12}{|c|}{ University of Patras } \\
\hline & \multicolumn{2}{|c|}{ Not at all } & \multicolumn{2}{|c|}{ A little } & \multicolumn{2}{|c|}{ Quite } & \multicolumn{2}{|c|}{ Much } & \multicolumn{2}{|c|}{$\begin{array}{l}\text { Very } \\
\text { much }\end{array}$} & \multicolumn{2}{|c|}{ Total } \\
\hline & $\mathrm{N}$ & $\%$ & $\mathrm{~N}$ & $\%$ & $\mathrm{~N}$ & $\%$ & $\mathrm{~N}$ & $\%$ & $\mathrm{~N}$ & $\%$ & $\mathrm{~N}$ & $\%$ \\
\hline $\begin{array}{l}\text { The content of the } \\
\text { course is }\end{array}$ & 3 & 4 & 8 & 10.7 & 17 & 22.7 & 30 & 40 & 17 & 22.7 & 75 & 100 \\
\hline comprehensible & 0 & 0 & 1 & 1 & 26 & 25.2 & 54 & 52.4 & 22 & 21.4 & 103 & 100 \\
\hline $\begin{array}{l}\text { New skills related to } \\
\text { distance }\end{array}$ & 8 & 10.7 & 10 & 13.3 & 15 & 20 & 21 & 28 & 21 & 28 & 75 & 100 \\
\hline $\begin{array}{l}\text { education are being } \\
\text { developed }\end{array}$ & 1 & 1 & 5 & 4.9 & 8 & 7.8 & 32 & 31.1 & 57 & 55.3 & 103 & 100 \\
\hline $\begin{array}{l}\text { The teaching method } \\
\text { of }\end{array}$ & 5 & 6.7 & 21 & 28 & 23 & 30.7 & 18 & 24 & 8 & 10.7 & 75 & 100 \\
\hline $\begin{array}{l}\text { distance education } \\
\text { covers the } \\
\text { prerequisites of the } \\
\text { course }\end{array}$ & 0 & 0 & 6 & 5.8 & 37 & 35.9 & 50 & 48.5 & 10 & 9.7 & 103 & 100 \\
\hline $\begin{array}{l}\text { The new way of } \\
\text { teaching is }\end{array}$ & 9 & 12 & 16 & 21.3 & 22 & 29.3 & 17 & 22.7 & 11 & 14.7 & 75 & 100 \\
\hline interesting & 0 & 0 & 6 & 5.8 & 22 & 21.4 & 43 & 41.7 & 32 & 31.1 & 103 & 100 \\
\hline $\begin{array}{l}\text { Communication with } \\
\text { the }\end{array}$ & 7 & 9.3 & 15 & 20 & 26 & 34.7 & 22 & 29.3 & 5 & 6.7 & 75 & 100 \\
\hline teacher is satisfactory & 0 & 0 & 6 & 5.8 & 29 & 28.2 & 42 & 40.8 & 26 & 25.2 & 103 & 100 \\
\hline $\begin{array}{l}\text { Student participation } \\
\text { in the }\end{array}$ & 10 & 13.3 & 19 & 25.3 & 19 & 25.3 & 20 & 26.7 & 7 & 9.3 & 75 & 100 \\
\hline course is great & 0 & 0 & 4 & 3.9 & 26 & 25.2 & 47 & 45.6 & 26 & 25.2 & 103 & 100 \\
\hline Attendino is easy & 7 & 9.3 & 8 & 10.7 & 20 & 26.7 & 22 & 29.3 & 18 & 24 & 75 & 100 \\
\hline Atlending is easy & 0 & 0 & 4 & 3.9 & 23 & 22.3 & 40 & 38.8 & 36 & 35 & 103 & 100 \\
\hline $\begin{array}{l}\text { The interaction } \\
\text { between teacher and } \\
\text { students is }\end{array}$ & 10 & 13.3 & 19 & 25.3 & 27 & 36 & 14 & 18.7 & 5 & 6.7 & 75 & 100 \\
\hline satisfactory & 2 & 1.9 & 10 & 9.7 & 33 & 32 & 41 & 39.8 & 17 & 16.5 & 103 & 100 \\
\hline $\begin{array}{l}\text { The interactions } \\
\text { between }\end{array}$ & 23 & 30.7 & 23 & 30.7 & 12 & 16 & 14 & 18.7 & 3 & 4 & 75 & 100 \\
\hline $\begin{array}{l}\text { students } \\
\text { satisfactory }\end{array}$ & 6 & 5.8 & 30 & 29.1 & 34 & 33 & 25 & 24.3 & 8 & 7.8 & 103 & 100 \\
\hline
\end{tabular}


(36\%-66\%). This probably means that UP students, in comparison with DUTH students, find the new way of teaching much more interesting and are much more satisfied with their participation in the courses as well as with the way teachers communicate with students. Attending the course seems to be easier for UP students. On the contrary, one in five DUTH students is experiencing difficulties.

Other characteristics mentioned by less students refer to the argument that the teaching method of distance education covers the prerequisites of the course $(34.7 \%-58.2 \%)$ and that the interaction between teacher and students is satisfactory $(25.4 \%-56.3 \%)$. We could therefore conclude that teacher-student interaction is more rewarding for UP students. It is also worth mentioning that the interaction among students collects the smallest percentage of responses $(22.7 \%-32.1 \%)$. It seems that the interaction of students with each other seems to be problematic, especially for DUTH students, $61.4 \%$ of whom believe that the interaction is not at all or a little satisfactory.

Regarding therefore, the negative characteristics that students identify in online education, in relation to the usual educational context, the elements mentioned are related to issues of poor interaction, cooperation and socialization in the academic context. Generally, there is more concern among DUTH students, having a more negative mood in most indicators.

\subsection{Factors Affecting E-Learning}

In assessing the factors that affected e-learning (Table 4), the DUTH students did not seem to particularly care (much/very much) whether the instructor"s camera was turned on $(25.4 \%)$, while UP students find it more important $(58.3 \%)$. On the other hand, there is a common view between the two Universities on the instructor"s adequacy in handling the platform, as is stated (much/very much) by the majority of the participants $(61.3 \%-62.5 \%)$.

More than half of the DUTH students but less of the UP students (52\%-44.7\%) were deeply concerned about the inability to work with their classmates, while for students of both Universities their views about the lack of visual contact were split, with an exception of the ,very much" answers of UP students, where the percentage is very low $(8.7 \%)$. It seems that DUTH students seek a little more than UP students the cooperation and the eye contact with their fellow students.

Table-4. Factors affecting students" e-learning

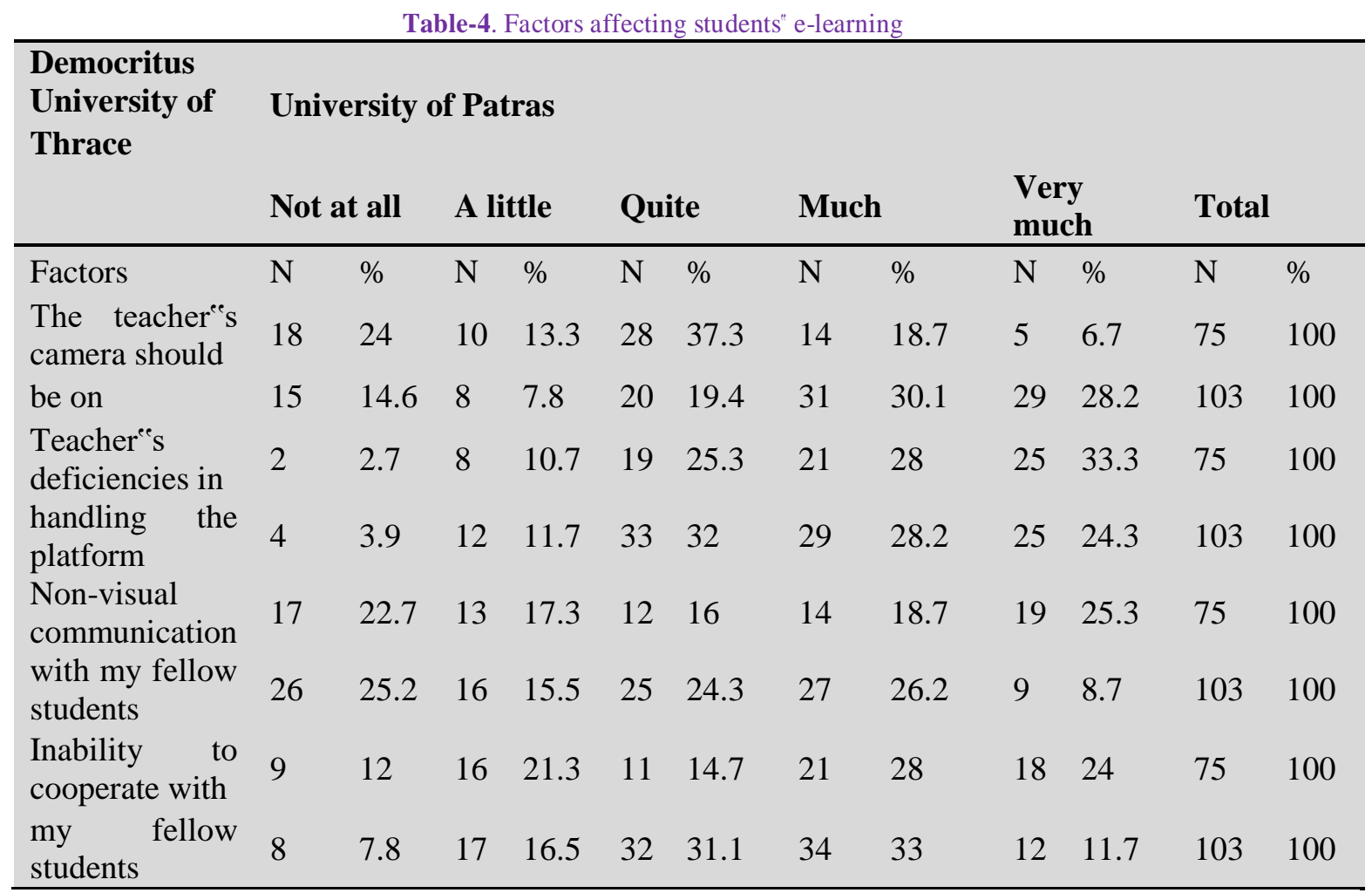

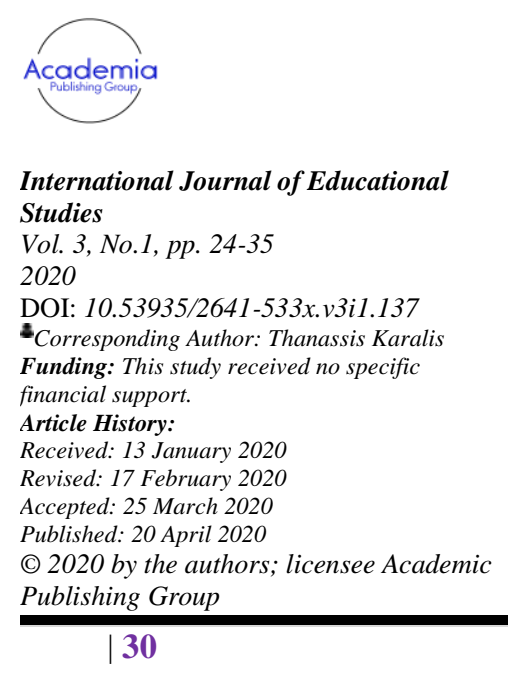

International Journal of Educational

DOI: $10.53935 / 2641-533 x .3 i 1.137$

Corresponding Author: Thanassis Karalis Funding: This study received no specific

Received: 13 January 2020

Acceped: 25 March 2020

| 30 
Students were also asked about their preferred types of communication during delivery of lessons (Table 5). In both Universities students preferred mostly (much/very much) chat to written communication to pose questions (54.7\%-67.9\%) rather than speaking on their microphone during the electronic class (41.3\%-44.7\%). Generally, students at the DUTH seem to be more reluctant to speak into the microphone. Text messages is the main mode of communication during the course for both Universities, although in the DUTH there seems to be a greater aversion to them as well.

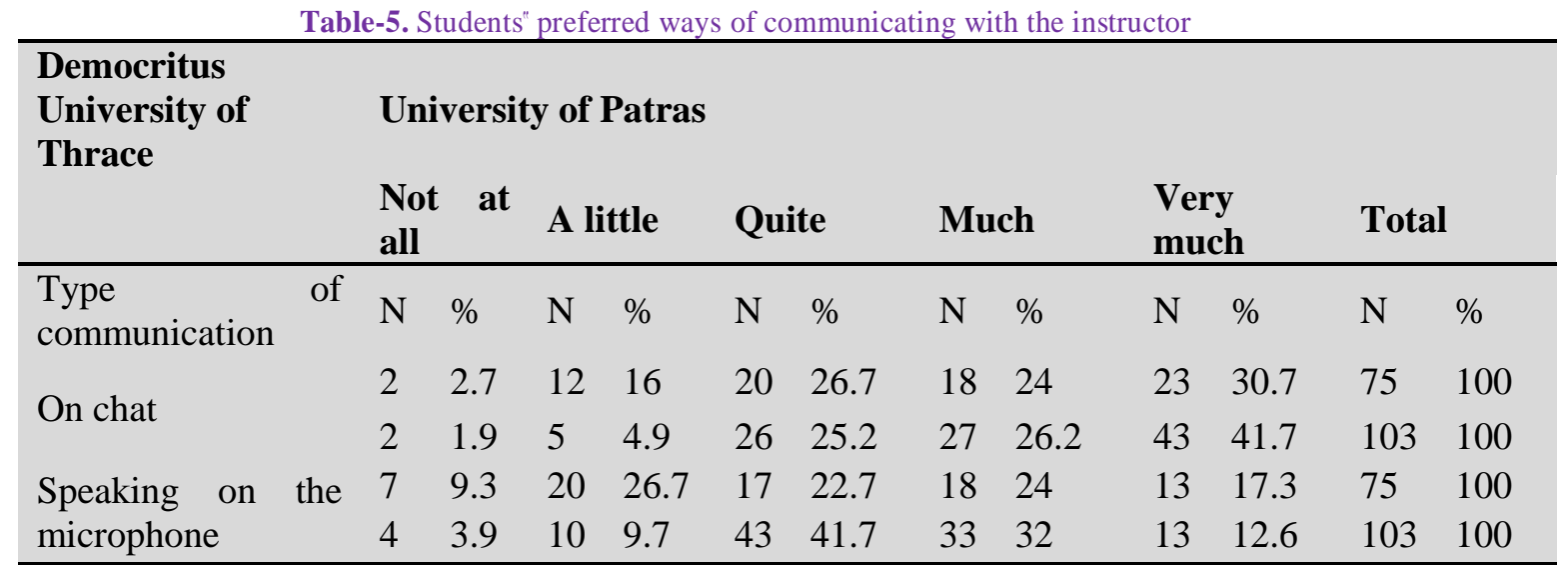

4.5. What Aspects of their University life did the Students Miss?

Table-6. Elements of regular education that are missing from online education

\begin{tabular}{|c|c|c|c|c|c|c|c|c|c|c|c|c|}
\hline \multirow[t]{3}{*}{$\begin{array}{l}\text { Democritus } \\
\text { University of } \\
\text { Thrace }\end{array}$} & \multicolumn{12}{|c|}{ University of Patras } \\
\hline & \multicolumn{2}{|c|}{$\begin{array}{l}\text { Not } \\
\text { all }\end{array}$} & \multicolumn{2}{|c|}{ A little } & \multicolumn{2}{|c|}{ Quite } & \multicolumn{2}{|c|}{ Much } & \multicolumn{2}{|c|}{$\begin{array}{l}\text { Very } \\
\text { much }\end{array}$} & \multicolumn{2}{|c|}{ Total } \\
\hline & $\mathrm{N}$ & $\%$ & $\mathrm{~N}$ & $\%$ & $\mathrm{~N}$ & $\%$ & $\mathrm{~N}$ & $\%$ & $\mathrm{~N}$ & $\%$ & $\mathrm{~N}$ & $\%$ \\
\hline \multirow{2}{*}{ Teachers } & 5 & 6.7 & 8 & 10.7 & 16 & 21.3 & 26 & 34.7 & 20 & 26.7 & 75 & 100 \\
\hline & 6 & 5.8 & 9 & 8.7 & 35 & 34 & 42 & 40.8 & 11 & 10.7 & 103 & 100 \\
\hline \multirow{2}{*}{$\begin{array}{l}\text { Fellow } \\
\text { students }\end{array}$} & 6 & 8 & 5 & 6.7 & 7 & 9.3 & 20 & 26.7 & 37 & 49.3 & 75 & 100 \\
\hline & 10 & 9.7 & 6 & 5.8 & 14 & 13.6 & 40 & 38.8 & 33 & 32 & 103 & 100 \\
\hline \multirow{2}{*}{ Library } & 9 & 12 & 12 & 16 & 20 & 26.7 & 16 & 21.3 & 18 & 24 & 75 & 100 \\
\hline & 17 & 16.5 & 21 & 20.4 & 37 & 35.9 & 14 & 13.6 & 14 & 13.6 & 103 & 100 \\
\hline \multirow{2}{*}{ Classes } & 6 & 8 & 9 & 12 & 17 & 22.7 & 19 & 25.3 & 24 & 32 & 75 & 100 \\
\hline & 12 & 11.7 & 9 & 8.7 & 34 & 33 & 33 & 32 & 15 & 14.6 & 103 & 100 \\
\hline $\begin{array}{l}\text { Live } \\
\text { communication }\end{array}$ & 4 & 5.3 & 4 & 5.3 & 14 & 18.7 & 19 & 25.3 & 34 & 45.3 & 75 & 100 \\
\hline $\begin{array}{l}\text { during the } \\
\text { lesson }\end{array}$ & 4 & 3.9 & 4 & 3.9 & 12 & 11.7 & 36 & 35 & 47 & 45.6 & 103 & 100 \\
\hline Social & 5 & 6.7 & 5 & 6.7 & 8 & 10.7 & 11 & 14.7 & 46 & 61.3 & 75 & 100 \\
\hline interaction & 0 & 0 & 3 & 2.9 & 10 & 9.7 & 34 & 33 & 56 & 54.4 & 103 & 100 \\
\hline
\end{tabular}

Finally, the element that students mention they miss about the University"es usual operating mode is mainly the social aspect (Table 6). Specifically, the majority of students in both Universities missed social interaction on campus (76\%-87.4\%), followed by face-to-face communication during lessons (70.6\%-80.6\%), their fellow students (76\%-70.9\%), as well as teachers $(61.4 \%-51.5 \%)$. Therefore, a remarkable lack of social interaction in both Universities is mentioned, although in the DUTH there is a 
higher proportion of people who do not care about it (not at all/a little). Generally, UP students miss social interaction on campus and face-to-face contact during lessons more than DUTH students. On the other hand, DUTH students seem to have greater need for contact with fellow students, as well as teachers.

As far as educational spaces are concerned, more DUTH students than UP students point out that they miss much/very much both the classrooms (57.3\%-46.6\%), and the University library (45.3\%$27.2 \%$ ), although much less. It seems that DUTH students have a greater need for the classrooms, because almost one in three say that they miss them ,very muche, which is more than twice the rate of UP students.

\section{Discussion}

The impact of COVID-19 on education systems worldwide is tremendous; more than 1.6 billion students have been affected, representing approximately $90 \%$ of all students worldwide (UNESCO, 2020). Many Universities used existing online courses from platforms such as Coursera, Jove etc. Research among 300 faculty members from different countries all over the world showed that half of higher education institutions in April 2020 had already developed e-learning systems to cover 100\% of their educational needs, to cope with closure of Universities due to Covid lockdown (QS 2020). Greek Universities however, with courses taught in Greek, could not use these platforms, since English is usually the language used for instruction thus, most educators hastily adapted their courses to distance learning. But when lockdown knocked our door, due to COVID-19 pandemic, like all Greek Universities, the University of Patras (UP) and the Democritus University of Thrace (DUTH) provided academic continuity for the semester via distance learning.

Since we don't know exactly how COVID-19 affected Higher education in Greece, we cannot figure its impact on Greek students. Nevertheless, recent data (Karalis \& Raikou, 2020; Kedraka \& Kaltsidis, 2020) suggest that, beyond several concerns students had, it could have a lasting and beneficial impact on educational learning acting as a catalyst for change. It seems thus, that for Greek Universities which are characterized by a slow pace of change, and still in most cases use lecture-based approaches in teaching (Kedraka, 2016; Rotidi, Kedraka, Frementiti, \& Kaltsidis, 2020), the effect of COVID-19 pandemic, offered an excellent opportunity -and at the same time a challenge- to move towards digitization. We cannot ignore, though, that the sudden introduction of distance learning has brought out several issues regarding aspects of e-learning, especially those connected to emotions and attitudes.

In the current study, students at the University of Patras and Democritus University of Thrace were asked about their feelings when the institutions suspended its educational function due to the pandemic of COVID-19. Based on findings regarding emotions that arose when the lockdown of Universities was announced, we argue that most students in both Universities experienced negative emotions -mainly anxiety. It seems that students from the University of Patras were more concerned about their studies in comparison to students from the Democritus University of Thrace. These feelings were focused on the completion of their studies, implying that beyond personal anxiety due to the abrupt change in their studies and plans, maybe Greek students do not feel secure in their educational environment. Illeris (2007) in his Holistic Theory of Learning underlines the importance of the educational environment, the framework within the learning process takes place, as one of the most important dimensions learning depends on. Therefore, students" implied feelings of uncertainty that the institution will not respond properly to thei xxr needs or the new demands deriving from the crisis, is something leaders of higher education institutions in Greece maybe have to take seriously into account.

It is interesting, though, that when students were asked how they felt when the courses restarted, in the online form, the great majority of students in both Universities stated a clear change of emotions, towards a positive direction. They expressed relief, satisfaction, and joy that the semester would not be lost, as well as curiosity about how their studies would be continued. The distance learning process led even to enthusiasm for the new experience, suggesting that e-learning, in some capacity, could be an organic part of higher education; meaning this may be an opportunity to introduce in Greece, innovative approaches using digital tools.

Students were asked to evaluate the online mode of education, in relation to the usual context. They seem to positively value the comprehensibility and understanding of the course content, the development 


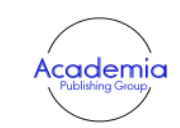

International Journal of Educational Studies

Vol. 3, No.1, pp. 24-35

2020

DOI: $10.53935 / 2641-533 x . v 3 i 1.137$

Corresponding Author: Thanassis Karalis Funding: This study received no specific financial support.

Article History:

Received: 13 January 2020

Revised: 17 February 2020

Accepted: 25 March 2020

Published: 20 April 2020

(C) 2020 by the authors: licensee Academic

Publishing Group

| 33 of new skills and the convenience of attending courses, along with the acquisition of better ICT skills related to distance learning, possibly because they feel that it will be useful to them later in their career. In distance learning students have the opportunity to work in their own environment, time and pace allowing them studying according to their individual characteristics. Moreover, e-learning gives all persons more opportunities to study, since it provides the more convenient access to higher education for people from special groups, eg, with disabilities (Koutselini, 2020). However, a large percentage of the University of Patras students but a smaller percentage of the Democritus University of Thrace students seem to consider that distance courses lack the vividness of face-to-face courses and they seem to miss communication and strong interest deriving from teaching in classroom. It seems though, that the most important negative elements that students -especially for Democritus University of Thrace studentsidentify in online education, in relation to the usual educational context, is the poor interaction with each other and with faculty, along with unsatisfactory cooperation and socialization in the academic context. The poor pedagogical approaches within the digital education tools, is an old problem concerning the delivering of e-courses. As research findings show (OECD, 2003), the main factor of effectiveness in digital education is the teacher, and the abilities and skills teachers have developed in order to turn this modern, convenient, flexible, and ubiquitous mode of teaching to an interesting learning experience for their students. Of course, transformations on their relationship with knowledge, learners, and the media they use in their teaching are necessary, but it is not clear that faculty members own them.

Attending the distance courses seems to be easier for University of Patras students compared to Democritus University of Thrace students, who seem to be experiencing difficulties. This finding could be attributed to the different scientific field, since developing teaching different disciplines into a distance teaching environment, needs different insights into how learning occurs, moreover via elearning methodologies, which require strong support not only in the pedagogical field but also in the technological field.

According to the European Universities Association (2020) digital transformation of educational institutions must be supported by experimentation in teaching models and methods, taking also into account teaching demands different disciplines require, as well as resources to conduct applied research, to improve their internal teaching and learning processes. Pilot studies and trials of teaching models for blended and online education are necessary for both educators and students to develop digital competencies (Delgado, Alario-Hoyos, \& Muñoz-Merino, 2019). Baxter and Hainey (2018) argue whether Universities have the potential to support and provide novel pedagogical avenues towards teaching and learning, in order to combine the benefits and potential drawbacks of distance learning with a focus in an educational context.

Indeed, students were deeply concerned about the inability to work with their classmates, while they mention the lack of visual contact, implying the significance of the eye contact during delivery of lessons.

In both Universities students seem rather reluctant to turn on their cameras, but they rather prefer to use the chat option to share their opinions and to pose questions. It seems that texting is mostly familiar to this young generation, as it is the main mode of communication within the social media, which are vastly used by them. It could also be a teaching problem, since lecturers are puzzled how to maintain the same depth of engagement with students, they could have in a face-to-face course setting. Learning and collaborating in an online environment might not always come easily to teachers and students (OECD, 2020).

Finally, the element that students mention they mostly miss from the University's usual operating mode is socializing: social interaction on campus, the face-to-face communication during lessons, their fellow students, as well as teachers -even aspects of students" life not so popular like the library. It is interesting to note that students didn't seem to enjoy this temporary break from academic life, on the contrary, they rather preferred to go on as usual with their studies. These findings are in accordance with studies in other countries (Dutta \& Smita, 2020), that came to the same results, despite cultural differences that could be mentioned among students from different countries and civilizations. 


\section{Thoughts for the Future}

World Economic Forum (2020) and the World Bank in its 2020 agenda proposals for the after COVID-19 era, both underline the need for a rebirth of education systems, after the pandemic "shock" and urge stakeholders (educators, learners, policy-makers and society at large) in developed countries, like Greece, to consider options in digital teaching for all disciplines. The real challenge, thus for the Universities in Greece is to exploit distance learning methods to improve the quality of teaching and learning leading to a transformation in the higher education that may have enormous impact on the economic and social level, as e-learning brought out issues like the need on reducing costs, or providing alternatives for special groups of students, eg, students with disabilities or coming from remote areas of living (Snyder, 2020).

\section{References}

Baxter, G., \& Hainey, T. (2018). Student perceptions of virtual reality use in higher education. Journal of Applied Research in Higher Education, 12(3), 413-424.

Charissi, A. (2020). The educational autobiography as a critical reflection tool towards personal and professional development of preservice early years practitioners. European Journal of Education Studies, 7(2), 71-89.

Charissi, A., Tympa, E., \& Karavida, V. (2020). Impact of the COVID-19 disruption on university students ${ }^{\text {ee }}$ perceptions and behavior. European Journal of Education Studies, 7(11), 222-238.

Coombs, P. H. (1968). World education crisis: A systems approach. New York: Oxford University Press.

Delgado, K. C., Alario-Hoyos, C., \& Muñoz-Merino. (2019). What can you do with educational technology that is getting more human? Paper presented at the In 2019 IEEE Global Engineering Education Conference (EDUCON). IEEE.

Dutta, S., \& Smita, M. K. (2020). The impact of covid-19 pandemic on tertiary education in Bangladesh: Students ${ }^{\text {ee }}$ perspectives. Open Journal of Social Sciences, 8, 53-68.

European Universities Association. (2020). Paper titled: Transforming university education: The UC3M Way. Retrieved from: https://eua.eu/downloads/publications/2020.1.9\%20delgado\%20kloos_alario-hoyos.pdf

Giavrimis, P., \& Nikolaou, S. M. (2020). The Greek University students ${ }^{\text {ee }}$ social capital during the COVID-19 pandemic. European Journal of Education Studies, 7(8), 1-16.

Gougoulakis, P., Kedraka, K., Oikonomou, A., \& Anastasiades, P. (2020). Teaching in tertiary education-a reflective and experiential approach to university Pedagogy. ACADEMIA, 21, 101-137.

Illeris, K. (2007). How we learn: Learning and non-learning in school and beyond. Routledge: London.

Kamarianos, I., Adamopoulou, A., Lambropoulos, H., \& Stamelos, G. (2020). Towards and understanding of University students ${ }^{\text {ce }}$ response in times of pandemic crisis (COVID-19). European Journal of Education Studies, 7(7), 20-40.

Karalis, T. (2016). Cascade approach to training: Theoretical issues and practical applications in non-formal education. Journal of Education and Social Policy, 3(2), 104-108.

Karalis, T. (2020). Planning and evaluation during educational disruption: Lessons learned from COVID-19 pandemic for treatment of emergencies in education. European Journal of Education Studies, 7(4), 125-142.

Karalis, T., \& Raikou, N. (2020). Teaching in times of COVID-19: Inferences and implications for higher education pedagogy. International Journal of Academic Research in Business and Social Sciences, 10(5), 479-293.

Kedraka, K. (2016). University pedagogy: Past, present and future. In K. Kedraka (ed), ." In Proceedings of the Symposium: "University Pedagogy: Education and teaching in tertiary education, a terra incognita?

Kedraka, K., \& Kaltsidis, C. (2020). Effects of the COVID-19 pandemic on University Pedagogy: Students ${ }^{\text {ee }}$ experiences and considerations. European Journal of Education Studies, 7(8), 17-29.

Kedraka, K., \& Rotidi, G. (2017). University pedagogy: A new culture is emerging in greek higher education. International Journal of Higher Education, 6(3), 147-153.

Koutselini, M. (2020). Quality assurance of e-learning within higher education: The philosophical and operational framework. Academia, 18, 132-144.

Maloney, E., \& Kim, J. (2020). The low-density university: 15 scenarios for higher education. Baltimore: Johns Hopkins University Press.

OECD. (2003). What schools for the future, schooling for tomorrow. In Organisation for Economic Co-operation and Development, 37. Paris: OECD.

OECD. (2020). Education responses to covid-19: Embracing digital learning and online collaboration. Retrieved from: https://oecd.dam-broadcast.com/pm_7379_120_120544-8ksud7oaj2.pdf.

Raikou, N., \& Karalis, T. (2011). Exploring the potential of transformative learning in higher education: The development of students" critical thinking through aesthetic experience. Paper presented at the In 9th International Conference on Transformative Learning, Athens, 28-29 May 2011. In M. Alhadeff-Jones, \& A. Kokkos (eds.).

Raikou, N., Karalis, T., \& Ravanis, K. (2017). Implementing an innovative method to develop critical thinking skills in student teachers. Acta Didactica Napocensia, 10(2), 21-30.

Rotidi, G., Kedraka, K., Frementiti, E. M., \& Kaltsidis, C. (2020). University pedagogy in greece: Pedagogical needs of greek academics from ionian university". In: A. Kavoura, E. Kefallonitis, P. Theodoridis (eds), strategic innovative marketing and tourism." In Springer Proceedings in Business and Economics. Cham: Springer.

Schleicher, A. (2020). OECD - the impact of COVID-19 on education: Insights from education at a glance 2020. Retrieved from: https://www.oecd.org/education/the-impact-of-covid-19-on-education-insights-education-at-a-glance-2020.pdf. 
Snyder, J. A. (2020). Higher education in the age of coronavirus. Boston Review: Retrieved from: http://bostonreview.net/forum/jeffreyaaron-snyder-higher-education-age-coronavirus.

UNESCO. (2020). Institute for statistics data, COVID-19 impact on education. Retrieved from: https://en.unesco.org/covid19/educationresponse.

World Economic Forum. (2020). How COVID-19 is driving a long-overdue revolution in education. Retrieved from: https://www.weforum.org/agenda/2020/05/how-covid-19-is-sparking-a-revolution-in-higher-education/.

Murphy, M. (2020). Universities beyond the coronavirus crisis - What awaits? University World News.

2020

DOI: $10.53935 / 2641-533 x . v 3 i 1.137$

Corresponding Author: Thanassis Karalis Funding: This study received no specific

financial support.

Article History:

Received: 13 January 2020

Revised: 17 February 2020

Accepted: 25 March 2020

Published: 20 April 2020

(c) 2020 by the authors; licensee Academic

Publishing Group 